\title{
A Review of the Research on Charter Schools
}

\author{
Katrina Bulkley \\ Jennifer Fisler
}

Follow this and additional works at: https://repository.upenn.edu/cpre_researchreports

Part of the Curriculum and Instruction Commons, and the Educational Assessment, Evaluation, and Research Commons

\section{Recommended Citation}

Bulkley, Katrina and Fisler, Jennifer. (2002). A Review of the Research on Charter Schools. CPRE Research Reports.

Retrieved from https://repository.upenn.edu/cpre_researchreports/26

View on the CPRE website.

This paper is posted at ScholarlyCommons. https://repository.upenn.edu/cpre_researchreports/26

For more information, please contact repository@pobox.upenn.edu. 


\title{
A Review of the Research on Charter Schools
}

\author{
Abstract \\ The major research areas over the last decade have focused largely on assessing how the \\ implementation of charter schools compares with the original theory. This review examines whether \\ charter schools are autonomous, innovative, accountable, and equitable. The review looks at existing \\ evidence about outcomes of students enrolled in charter schools and the broader effects of charter \\ schools on public education. The review provides a foundation for future work that will examine in greater \\ depth the role charter schools may play in educational reform. \\ Disciplines \\ Curriculum and Instruction | Educational Assessment, Evaluation, and Research \\ Comments \\ View on the CPRE website.
}




\title{
A Review of the Research on Charter Schools
}

\author{
Katrina Bulkley \\ Jennifer Fisler \\ CPRE Web Paper Series \\ WP-01 \\ June 2002 \\ University of Pennsylvania \\ Graduate School of Education
}

Consortium for Policy Research in Education

(C) Copyright 2002 by the Consortium for Policy Research in Education 


\section{Contents}

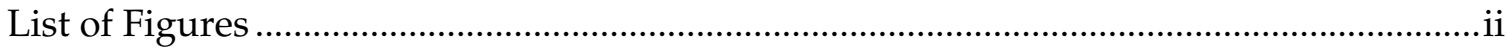

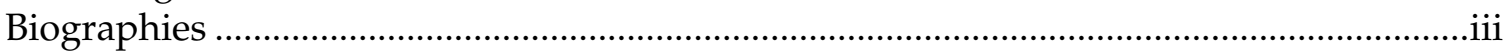

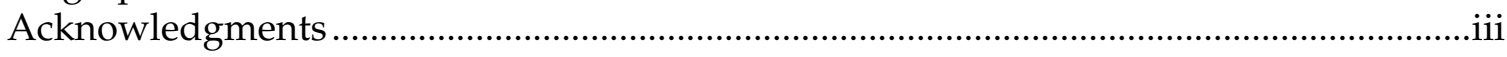

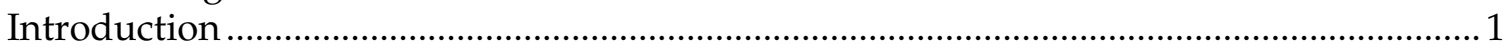

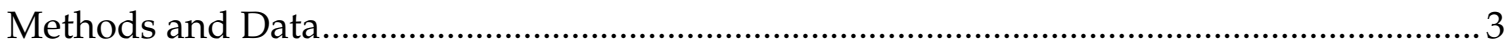

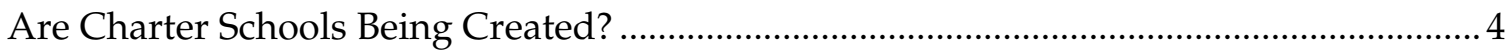

Are Charter Schools Truly Autonomous? ..................................................................... 5

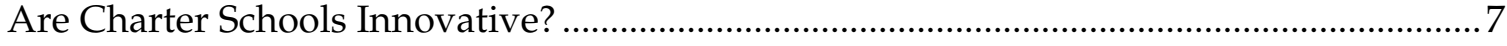

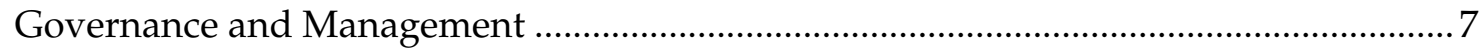

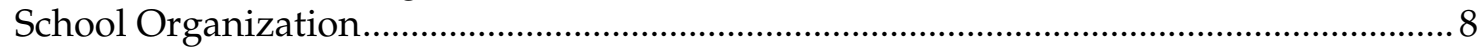

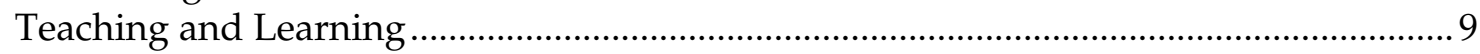

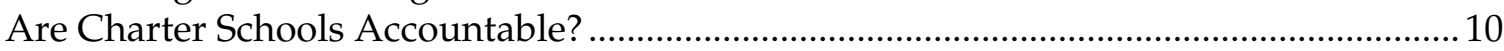

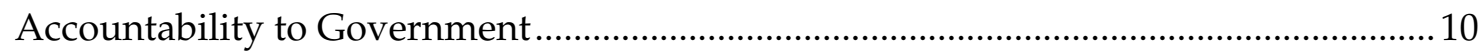

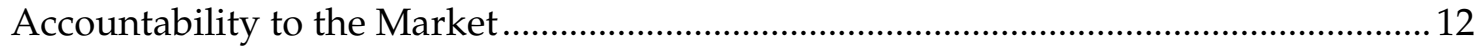

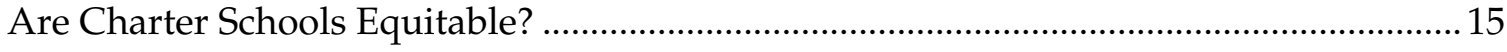

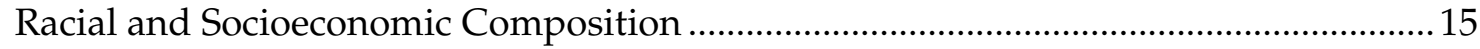

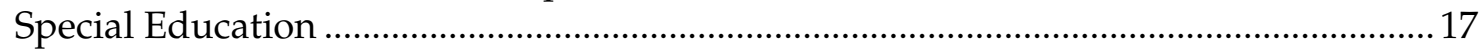

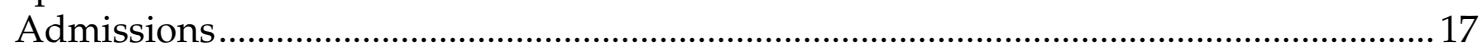

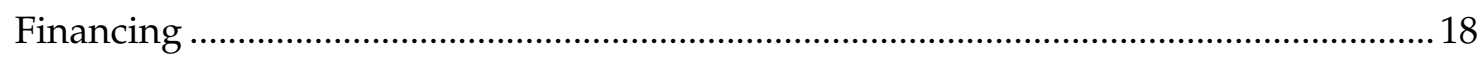

Are Charter Schools Leading to Educational Improvement? ............................................. 19

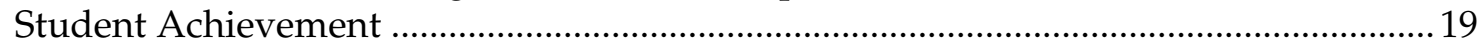

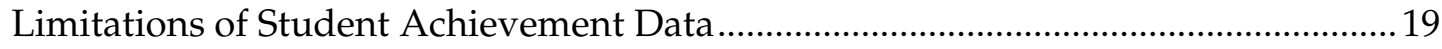

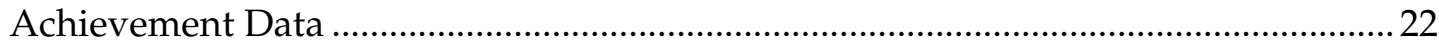

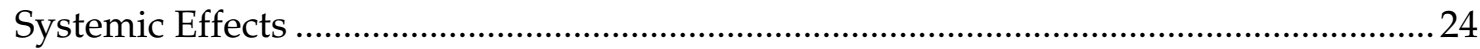

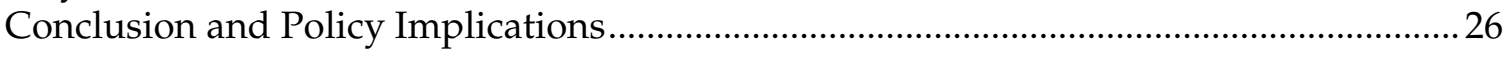

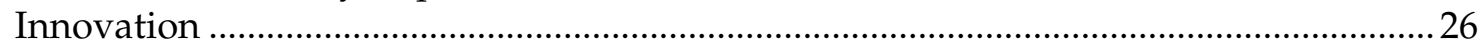

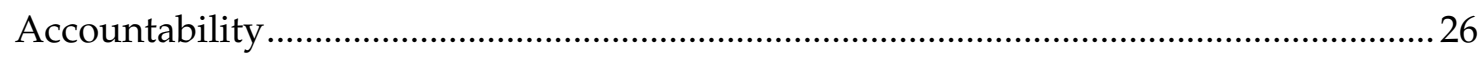

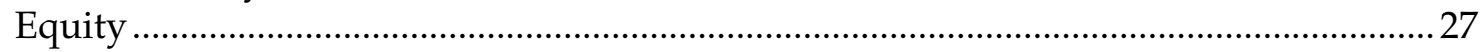

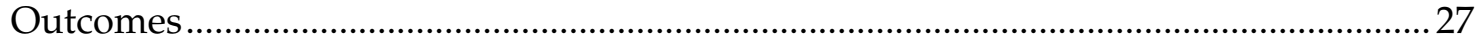

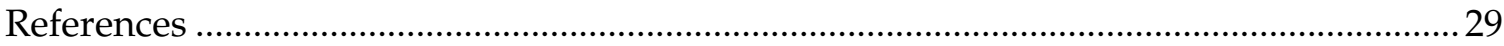

\section{List of Figures}

Figure 1. The Rationale for Charter Schools................................................................... 2 


\section{Biographies}

Katrina Bulkley is an Assistant Professor of Educational Policy at Rutgers University. Her work focuses on issues of school reform, particularly in the area of charter schools and school choice, with a focus on issues of state policy and accountability. Currently, she is working on a project funded by CPRE that examines educational management organizations that operate charter schools and the different ways in which companies and schools negotiate their relationships.

Jennifer Fisler is a Research Associate at the Center for Education Policy Analysis at Rutgers University, and has been involved with survey research and analysis in her work at Rutgers. She recently published an article based on survey research of undergraduate women in the sciences and has spent the last four years conducting a study using surveys and interviews to look at the professional development of teachers.

\section{Acknowledgments}

This paper is based on research conducted by CPRE. CPRE is sponsored by the National Institute on Educational Governance, Finance, Policymaking, and Management; Office of Educational Research and Improvement; U.S. Department of Education (OERI Grant No. R308A960003). Opinions expressed in this publication are those of the authors and do not necessarily reflect the views of the National Institute on Educational Governance, Finance, Policymaking, and Management; the Office of Educational Research and Improvement; the U.S. Department of Education; Rutgers University; CPRE; or its institutional members. 


\section{Introduction}

The number of schools operating under charter school laws has soared over the last decade, from a small number operating in just a few states to more than 2,300 schools serving over 575,000 students in 34 states and the District of Columbia. More than half of these schools are concentrated in a few states Arizona has over 400 charter schools, and California, Florida, Michigan, and Texas each has more than $150{ }^{1}$

Charter schools are relatively autonomous schools of choice that operate under a charter or contract issued by a public entity such as a local school board, public university, or state board of education. These contracts, usually lasting three-to-five years, provide school operators more autonomy than afforded a district-run public school in exchange for enhanced accountability by requiring schools to prove they are worthy of succeeding contracts.

It is important to note that charter schools are an institutional innovation, meaning the laws allow schools to operate under a different structure. Charter school laws are not an attempt to endorse any particular learning approach or curriculum in the schools. Ted Kolderie, one of the creators of the charter school concept, explained, "... the chartered school is not a kind of school; not a learning program or method. The opportunity the law provides is an empty institutional structure, as a building is an empty physical structure. Students learn from what the organizers put into it" (personal communication, October 25, 2001). ${ }^{2}$ Thus, in comparing schools

\footnotetext{
${ }^{1}$ See the Center for Education Reform web site: http://www.edreform.com.
}

operating under charter school laws with those directly operated by public school districts, it is necessary to consider the substantial variation under the charter school umbrella.

The U.S. Department of Education commissioned the Consortium for Policy Research in Education (CPRE) to review the research on charter schools. This review expands upon the themes raised in the CPRE Policy Brief, A Decade of Charter Schools: From Theory to Practice. This literature review examines some key areas in the charter school research and, based on the research, attempts to compare the implementation of charter schools with the original expectations of their advocates (for origins of the charter school idea, see Budde, 1988; Kolderie, 1990; Nathan, 1996). Charter school laws vary in terms of their components and in the intentions of policymakers when adopting them (Buechler, 1996; Lake \& Millot, 1998; Wohlstetter, Wenning, \& Briggs, 1995). Political compromises have sometimes enabled the passage of charter school laws, but created challenges for their implementation (see Hassel, 1999). Despite the variations among charter schools, some elements are common to the concept as shown in Figure 1. Organized by these common elements, the following paper examines how research can inform each facet of charter schools.

Advocates identified five components of the theory of charter schools:

- Adoption of charter school laws would lead to the creation of new or reinvention of existing schools (public and/or private, depending on the state law), thereby expanding both the number and variety of school choices

\footnotetext{
${ }^{2}$ Kolderie (1998) made a similar argument in an article for the Charter Friends Network.
} 
Figure 1. The Rationale for Charter Schools

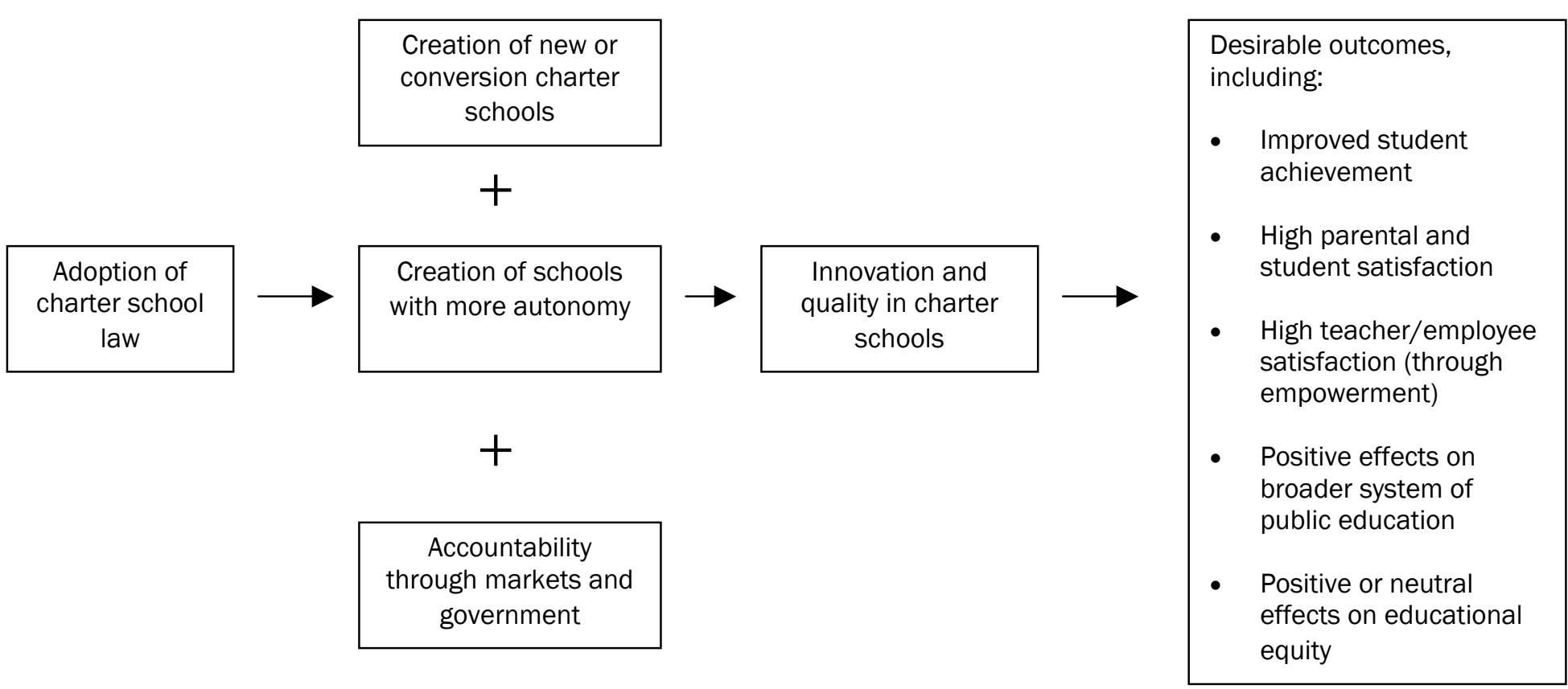

available to parents (Kolderie, 1990; Nathan, 1996).

- Charter schools would have more autonomy and flexibility than districtoperated public schools by virtue of their independence from school districts, waivers from state laws and regulations, and student/parent choice (Wohlstetter, Wenning, \& Briggs, 1995).

- Interplay of autonomy and market forces would make charter schools more innovative and of higher quality than district-run public schools in areas of instruction and curriculum, school organization and governance, and in some cases, teacher qualifications and union involvement (Arsen, Plank, \& Sykes, 1999).

- Charter schools would be more accountable than district-run schools because they would have to meet demands of parent and student consumers and of short-term performance contracts with government agencies that provide public funding.

- The combination of autonomy, innovation, and accountability would lead to improved student achievement, high parental and student satisfaction, high teacher satisfaction and empowerment, positive effects on the broader system of public education, and positive or neutral effects on educational equity, including better services for at-risk students.

Charter school advocates were optimistic about the potential impact of charter schools, but they also anticipated practical and political challenges, including resistance from local school districts (Kolderie, 1990). 
The major research areas over the last decade have focused largely on assessing how the implementation of charter schools compares with the original theory. This review examines whether charter schools are autonomous, innovative, accountable, and equitable. The review looks at existing evidence about outcomes of students enrolled in charter schools and the broader effects of charter schools on public education. The review provides a foundation for future work that will examine in greater depth the role charter schools may play in educational reform.

\section{Methods and Data}

Accompanying the growth of charter schools in an increasing number of states has been a burgeoning literature on charter school policies and practices. This review is not a comprehensive overview and analysis of all research on charter schools, but focuses on a subset of the literature. The primary documents reviewed were state evaluations, federally-funded studies that were national in scope, and other studies that have received substantial attention in the charter schools research community. The data were analyzed based on the themes of the original intent of the charter school concept. Studies that were representative of these overall themes are described and cited where appropriate. A total of 52 studies of operating charter schools and documents exploring the origins of the charter school concept have been reviewed.

Reviewing this literature presents several challenges. While the data sources can provide excellent research, they must be read carefully. Many studies, particularly in the early charter school years, were funded by organizations having strong viewpoints - both supporters and critics - on the idea of charter schools. Advocates and those skeptical of the charter school concept have been among those most engaged in studying the reform. Later studies, especially those funded by the U.S. Department of Education, have generally presented a more objective analysis of charter school implementation.

Determining how to interpret studies that aggregate findings across charter schools, as opposed to looking for patterns among schools or treating each school separately, presents another challenge. The tendency has been generally to aggregate schools (especially in evaluations) in order to determine broad benefits of the charter school reform. This is necessary to some extent to answer important policy questions about charter school laws. Aggregating charter school results (where the primary similarity is structural, rather than educational), however, can mask the particular where and why individual schools are meeting expectations or struggling to stay afloat.

Research focused on charter schools in specific states presents a third challenge because different state political and cultural contexts and provisions in their laws can strongly influence the process and outcomes of charter schools. The structural conditions of each state vary, so comparisons across studies in different states can be difficult. Also, the experiences of states like California and Michigan, where there has been considerably more research, could possibly receive disproportionate attention.

In our analysis, we have attempted to balance these challenges in our effort to provide a full overview of what is known about the implementation of charter 
schools. In drawing on data from multiple states, we have attempted to highlight these interpretive challenges, especially in the area of student achievement data.

\section{Are Charter Schools Being Created?}

The entire theory of charter schools rests on the assumption that, given the opportunity, a significant number of individuals and organizations will invest considerable resources in starting new or converting existing schools into charter schools. This assumption seems well supported by the experience of the last decade. The passage of charter school laws has resulted in rapid growth in this new educational sector. More than 2,300 schools are currently operating nationwide and continued growth seems likely.

Why do people decide to establish a charter school? There are many reasons, just as there are many kinds of schools and operators. The motivations of those founding new-start schools differed somewhat from those that converted existing public schools. For example, public school personnel were more often interested in gaining increased autonomy than were operators of newly started schools.

Reasons for founding a charter school include a desire to realize an alternative vision of schooling, to serve a specific population, or to gain greater autonomy (RPP International, 2000). Problems and challenges encountered in starting a charter school are often related to start-up funds, operating funds, planning time, facilities, state or local board opposition, regulations, and collective bargaining issues (RPP International, 2000). Start-up funding problems appear to have decreased somewhat over time, in part because of increased federal and state assistance (RPP International, 2000; SRI International, 2000). Finding money for acquisition of appropriate facilities may be the biggest logistical and financial hurdle for schools that are not conversions of existing public schools. Financing of charter schools generally varied in amount and source across states and localities (Nelson, Muir, \& Drown, 2000).

In addition to these tangible difficulties, starting a charter school requires major commitments of staff time and energy, and often that of parents and others (see WestEd \& University of Southern California, 1998). Wohlstetter and Griffin (1998) have noted that "it is very hard work to design and operate a school that maintains its focus on teaching and learning" (p. 2) (see also Sarason, 1998).

Attracting consumers is an essential part of starting a charter school. A number of studies have examined the reasons parents and students select charter schools (for example, Miron \& Nelson, 2000, and RPP International, 1998). One California study identified educational programs, opportunities for parental involvement, safety, technology, better teachers, and location as chief motivating factors (WestEd \& University of Southern California, 1998).

Dissatisfaction with the previous school was a factor for parents of students with disabilities, and probably for other parents as well (Fiore, Harwell, Blackorby, \& Finnigan, 2000).

Charter schools nationwide have student demographics similar to other public schools. According to the RPP International study (2000), charter schools 
nationally enrolled approximately $11 \%$ fewer White students, $7 \%$ more African American students, 3\% more Hispanic students, slightly higher percentages of students eligible for free or reduced-price lunch, and about the same percentage of students having limited-Englishproficiency as regular public schools. Student and school characteristics, however, vary considerably across the country, with charter schools in some states far more likely to serve urban and at-risk students (RPP International, 1999). There is evidence in at least some states that charter schools are more likely to be located in urban areas (Arsen, Plank, \& Sykes, 1999).

Charter schools tend to be much smaller than district-operated schools; charter schools have a median enrollment of 137 students in comparison to the 475student enrollment of district schools (RPP International, 2000). Approximately $70 \%$ of the schools in the RPP study were new-start schools, 20\% were former district-run public schools, and 10\% were former private sectarian and nonsectarian schools.

\section{Are Charter Schools Truly Autonomous?}

Perhaps no concept is as central to the charter school idea as "autonomy." Without autonomy, charter schools cannot provide unique educational options for children. They cannot serve as experimental "laboratories" or "lighthouses" from which other children can learn. And they cannot act as market competitors, threatening the public school monopoly and inducing it to change (Hassel, 1999 , p. 78).

It is hard to generalize about the autonomy of charter schools because autonomy has a variety of meanings and because there is so much variation across states. Wohlstetter, Wenning, and Briggs (1995), drawing on Lakoff's work, define autonomy as the "independence and selfdetermination of a community in its external and internal relations" (p. 338). The authors also see autonomy as involving self-management by schools. Autonomy generally encompasses the ability of individual schools - within boundaries determined by government to make decisions concerning both internal operations and external relationships (including those with the state, district, or charter school authorizing agencies) and decisions about the critical issues of budgeting, hiring, and the educational program.

Half of the states with charter school laws automatically waive many state laws, rules, and regulations for charter schools. Waivers are uncommon in areas such as fiscal requirements (although there may be an alternate reporting system) and student assessment policies, but more common in collective bargaining and teacher certification (SRI International, 2000). Colorado charter schools can request waivers from specific state requirements. One study found that 97\% of Colorado's charter schools requested multiple waivers as part of their charter contract; these waivers were largely related to control over curriculum and employment/personnel issues (Clayton Foundation, 1999).

One four-state study concluded that politics affected how much autonomy individual schools had from state requirements. Hassel (1999) found that, when the political climate was generally supportive of charters, schools had similar experiences even though their states had varying amounts of deregulation. A recent national study found that most charter schools had 
primary control over purchasing, hiring, scheduling, and curriculum, while slightly fewer charter schools controlled student assessment and their budgets (RPP International, 2000). ${ }^{3}$ Two California studies found high levels of autonomy over personnel (Wells, 1998; WestEd \& University of Southern California, 1998). State governments face a continuing tension between ensuring that charter schools operate in ways consistent with the broad public interest and not recreating the existing bureaucratic system.

Two factors appear to have a particularly strong impact on charter school autonomy: whether or not the authorizing agency is a local school district, and whether or not the school was a public school converted to charter status. Based on a survey of chartering agencies, SRI International (2000) concluded that "the charter school promise of increased flexibility in exchange for increased accountability may be occurring more frequently in charter schools that are sponsored by non-local agencies than in those sponsored by local agencies" (p. 39). A study by Wells (1998) found that some California school districts have tried to limit the autonomy of schools they authorize. The RPP International surveys (2000) found that "pre-existing public schools had less control than both newly created and pre-existing private schools in all areas of decision-making and policy setting" (p. 46). Some states have recently acted to increase charter school autonomy by expanding the types of agencies eligible to grant charters. The thinking behind these changes is that different agencies might allow different types and levels of autonomy (SRI International,

\footnotetext{
${ }^{3}$ In most states, charter schools that have more applicants than seats accept students through a lottery process.
}

2000). The involvement of educational management organizations has also been found to influence the amount of autonomy available to charter schools (Bulkley, 2001).

Autonomy is available, for the most part, through parental choice, although (as discussed below) questions have been raised about who has knowledge about charter schools and who has access through admissions.

Charter school advocates have generally considered more autonomy to be better (see Kolderie, 1990), but the research to date is not clear. One study found that schools operating with greater autonomy from their districts were better able to create and sustain learning communities and respond quickly to problems, but were more consumed by managerial decisions (Wohlstetter \& Griffin, 1998). Another study suggested that, despite their desire for autonomy, charter schools often turned to their local district's bureaucracy when they needed help (Wells, 1998). The frequency with which schools turn to their authorizers for assistance likely varies considerably between those charter schools authorized by school districts and those authorized by other government entities. The Wohlstetter and Griffin (1998) study suggested that the ability of schools to take advantage of autonomy may vary. They concluded, "Schools with weak organizational structures appeared to have more difficulty capitalizing on their autonomy to develop and foster a highquality learning community" (p. 23).

Research on how legislative variations on autonomy affect school decisionmaking and school quality could make a positive contribution to knowledge about charter schools. Another area for future research is the impact of educational 
management companies on the ability of individual schools to make decisions and on how they support schools in creating quality educational programs. Mintrom (2000) argues, "In many ways...such management companies [as National Heritage Academies and the Edison Project] fill the gap for the charter schools that in the traditional public school system is filled by the school district office" (p. 26).

Autonomy for charter schools does not mean that these schools should simply be left to fend for themselves. Rather, external support can be very important, ranging from helpful authorizing agencies to state charter school organizations and private entities that assist individual schools (such as the Charter School Resource Center operated by the Pioneer Institute in Massachusetts) (see Hill et al., 2001). A study of charter schools in New York found, "While all of our study schools wanted more independence from public education authorities, most of our interviewees sought to strengthen their schools through a mix of autonomy and connection" (Ascher, Jacobowitz, McBride, \& Wamba, 2000, p. 18).

\section{Are Charter Schools Innovative?}

Charter schools are an institutional innovation in how publicly-funded schools are governed and controlled. Charter schools differ from district-run public schools in several important ways: they have increased autonomy (especially from states and school districts), they are schools of choice, and they are operated under contract by a variety of parties. Some see innovation as an essential element of charter schools. For example, Mintrom (2000) argues: "For the charter school initiative to yield positive social returns, the schools themselves must experiment with aspects of pedagogy and school management to develop educational innovations" (p. iv).

Innovation can be difficult to define. Some argue that innovation means something that is altogether new, while others see innovation as something new to a particular context (for example, small size or a clearly focused mission). Innovation, as noted in one recent study, "does not always mean plowing virgin soil" (Finn, Manno, \& Vanourek, 2000, p. 91). Innovation and improved quality are not automatically linked: many existing educational practices are educationally sound, while innovative practices may not all be of high quality.

The theory of charter schools predicts that they would be more innovative in their practices than district-operated public schools. Arsen, Plank, and Sykes (1999) identify three core areas for innovation:

- Governance and management;

- School organization; and

- Teaching and learning.

The research about innovation in these three core areas is summarized in the following pages.

\section{Governance and Management}

Arsen, Plank, and Sykes (1999) argue that, "The most important charter school innovations are not about teaching and learning, but rather about control over school operations" (p. 53). In the context of institutional innovation, it is not surprising that the most change has been noted in the governance structures 
(Kolderie, 1998). The most important aspect of this change is probably the enhanced autonomy described above. The governance of charter schools is varied, including schools that are dominated by teachers, by administrators, and by parents. Parents are often more involved in charter schools than in district-run public schools. One California study noted the importance of school leaders: "While interviews reveal many stakeholders are involved in school decision-making, staff also report that administrators play a vital leadership role" (WestEd \& University of Southern California, 1998, p. 18). Another California study found that strong and well-connected leaders can play a critical role in starting and operating a successful charter school (Wells, 1998). Charter school leaders come from a variety of sources, ranging from parents to teachers to business people as well as traditionally certified administrators.

Non-profit or for-profit educational management organizations (EMOs) are an interesting organizational innovation found more often in charter schools than in district-run public schools. Schools contract with the EMO to manage some or all of their operations. The practice is much more prevalent in some states. In Michigan, $70 \%$ of charter schools contract with EMOs to perform services, ranging from accounting to managing all aspects of school operations (Arsen, Plank, \& Sykes, 1999). The reduced influence of teacher unions can be considered another management innovation of charter schools. A 1998 study funded by the National Education Association found that $68 \%$ of charter school teachers reported "little or no union involvement in their school" (Koppich, Holmes, \& Plecki, 1998, p. iv). This finding is not surprising in that many states allow teachers at some or all charter schools to decide whether or not they want to participate in union activities (including collective bargaining) at the individual school. Decreased union activity is probably related to the lower percentage of certified teachers in charter schools discussed below. Future research is needed to explore the relationships, if any, between decreased union involvement, EMOs, and high rates of teacher satisfaction.

\section{School Organization}

Innovations in school organization include school and class sizes, grade configurations, staffing patterns, and use of staff time (Arsen, Plank, \& Sykes, 1999). Charter schools tend to be much smaller than district-run public schools and almost half have grade configurations that vary from the traditional elementary, middle, and secondary patterns (RPP International, 2000). Charter schools are also more likely to innovate in grade placement of students. In Massachusetts, $76 \%$ of charter schools studied used at least some multi-age groupings (Rosenblum Brigham Associates, 1998).

Charter school teachers are less likely to be certified than their peers in districtoperated public schools (RPP International, 1999). Certification rates of charter school teachers, however, vary by state, from $100 \%$ in Kansas and Rhode Island to $49 \%$ in Illinois (RPP

International, 1999). A recent Texas study found that slightly more than half of their charter school teachers were certified (Texas Education Agency, 2000). The same Texas study found that teachers in non-at-risk schools $(52.5 \%)$ were more likely to be certified or working toward certification than those teaching in at-risk schools (37.7\%). There is evidence in some states that charter school teachers 
have less teaching experience than their public school peers (see Center for Applied Research and Educational Improvement, 1998).

\section{Teaching and Learning}

We know far less about what happens inside charter school classrooms than we know about how charter schools are organized and governed. A

Massachusetts study found that many charter schools had a strong "unifying focus," perhaps related to content (performing arts, for example) or a general approach to education (such as a democratic community) (Rosenblum Brigham Associates, 1998). A Michigan study concluded that charter schools were somewhat more likely to engage in curricular innovations (including back-tobasics approaches) than public schools, but were often "essentially working to create localized variations of practices that are already common within the broader public school community" (Mintrom, 2000, p. 29). Some of the most innovative practices in Michigan were taking place in charter schools, Mintrom noted, but many charter schools were not engaging in what respondents described as new practices. Key factors in making some Michigan charter schools more innovative were motivation, lack of constraints, and an inclusive, deliberative process within the school.

Few studies have looked broadly at pedagogy in charter schools. A 1997 study of California charter schools found that charters used a mix of traditional classroom-based instruction and other methods such as home-based instruction and independent study (SRI International, 1997). Another California study found that the majority of charter school teachers employed classroom organization, curriculum, and pedagogy "commonly found in non-charter public schools" (Wells, 1998, p. 52).

Little is known about types and diversity of professional development in charter schools. Charter school personnel in one study reported less professional development then "typically observed in high-performing schools" (Wohlstetter \& Griffin, 1998, p. 13). In contrast, Massachusetts charter school directors described professional development as "continuous," including teacher-teacher observations, time for teacher meetings, and teacher involvement in curriculum decisions (Rosenblum Brigham Associates, 1998).

Even if more school-level research existed, broad statements about practices within charter schools would be difficult to make because of the institutional nature of the charter school reform. Making general statements about instruction in charter schools would be somewhat inconsistent with a reform designed to allow a wide variety of curricular and pedagogical approaches.

Finally, the development of a strong learning community appears to be an important factor in creating quality charter schools. In their study of 17 charter schools, Wohlstetter and Griffin (1998) identified the following building blocks for developing a strong learning community: a clear and specific mission; a high-quality instructional program with clear curricula and pedagogy; an accountability system with clear performance standards, assessment strategies, and consequences based on performance; and school leadership that provides "the compass for development and sustenance of the charter school as learning community" (p. 19). 
The concept of innovation has been important to charter school reformers and researchers. However, findings of truly innovative practices (that is, practices not seen elsewhere) are rare, and new does not always mean better. This highlights the need for research focused on the quality of educational practices. In comparison with what is known about charter schools (such as the design of charter school laws), little is known about the quality of education, the tools used to deliver instruction, or the connections between educational quality and policy in charter schools. Instead of looking specifically for innovation, looking at effective educational programs and governance approaches, and realistic methods for disseminating such best practices, seems a more fruitful direction for research at this time. For example, are charter schools employing particularly promising practices more than districtrun public schools? If so, why and what is the relationship between educational practices, governance, and organization? Educational management organizations present another area for future research. If these EMOs grow as some have predicted (Arsen, Plank, \& Sykes, 1999; Molnar, 2001), then the implications for school quality, equity, and public and private accountability should be carefully examined.

\section{Are Charter Schools Accountable?}

Charter school accountability has two facets. The first facet involves accountability to government accountability to the authorizing agency that grants the charters that allow individual schools to operate, and accountability to other governmental entities that have legal requirements involving charter schools. The second facet involves accountability to the consumers of charter schools: the students and their parents. The market assumption is that consumers will demand, among other things, highquality education. The thinking is that these two facets are mutually reinforcing. Finn, Manno, and Vanourek (2000) argue that, in general, "The chief aim of accountability is to find and sustain good schools while weeding out or repairing bad ones" (p. 127).

\section{Accountability to Government}

Authorizing agencies and other state agencies address the same basic issues: evaluating and approving applications, overseeing schools during the contract period, and determining whether or not to renew charters at the end of the contract period (Lake \& Millot, 1998; Vergari, 2000). There is considerable variation in state approaches to governmental accountability, however, “...with some following a 'centralized' state agency approach, others a 'marketdriven' approach, and still others a 'district-based' approach that relies on local accountability within a framework of state testing" (RPP International, 2000, p. 3). There is also tension over and variation in who should be involved and what role should government entities other than the authorizing agency play. In Arizona, for example, "There was some agreement among stakeholders that the Arizona Department of Education has a role in holding charter schools accountable for performance," although the Department does not grant charters (Mulholland, 1999, p. 25). Despite variations among states and tensions over the authority of different government entities, all charter-granting agencies must address the same application, oversight, and renewal issues. 
Charter applications do not always set clear and measurable goals that can be used in assessing outcomes, a pattern consistent with general findings on educational performance contracts (Hannaway, 1999). Studies in California found contract goals ranging from the concrete and quantitative to the informal and process-oriented (SRI International, 1997; Wells, 1998). Colorado requires that charter school applications explicate the school's student performance standards, measurable objectives for student growth, and assessment and reporting procedures. In practice, however, some plans are very specific while others are "less susceptible to easy measurement" (Clayton Foundation, 1999, p. 51).

Nationally, the situation may be improving gradually. According to a recent study, every chartering agency reported that some or all of its schools had measurable goals in the area of student achievement (SRI International, 2000).

Several studies suggest that charter school authorizers, although they collect student achievement data, focus less on student performance than on more familiar matters such as compliance and financial stability (Bulkley, 1999; Henig, Moser, Holyoke, \& Lacireno-Paquet, 1999; Hill et al., 2001; SRI International, 1997). According to a recent national study, chartering agencies reported that during the charter-granting process they focused on curriculum, finances, and assessment; once schools were operating, they concentrated on student achievement, financial record-keeping, and compliance with federal and state regulations (SRI International, 2000).

RPP International surveys (2000) show that $96.4 \%$ of charter schools were using standardized assessments (usually in conjunction with other assessment measures) and reporting this information to their charter-granting agency as part of the oversight process. Requiring information, however, and acting upon that information are not the same. For example, in one California study, $85 \%$ of charter schools said they reported student achievement data to their sponsoring agency, but only $4 \%$ said that the sponsor "had ever requested specific actions or imposed sanctions in response..." (SRI International, 1997, p. 16, emphasis in original).

Revocation or non-renewal of charter contracts is the ultimate instrument of governmental accountability. But roughly two-thirds of the states with charter schools have not yet evaluated their schools for renewal (SRI International, 2000). A national study of charter school accountability found that for charter authorizers, "Finding ways to measure not only student achievement on standardized tests but the value-added qualities of charter schools has proven to be a challenge" (Hill et al., 2001, p. vi). ${ }^{4}$ It is not clear to what extent chartergranting agencies are using educational monitoring or evaluation in making serious decisions about whether individual schools should continue to operate. Another accountability study found that charter school authorizers faced difficult challenges when considering revocation or non-renewal of a school's charter. These include the following factors:

\footnotetext{
${ }^{4}$ Authorizing legislation in several states (including Texas, Louisiana, and New Hampshire) requires charter schools to demonstrate acceptable levels of performance or improvement, based at least in part on test scores (Lake E Millot, 1998). It is unclear what effect this requirement will have on charter renewal in these states.
} 
- It is not easy to define or measure educational performance or program quality;

- Aspects of the school other than test scores are important to families and charter authorizers, so authorizers may use proxies to assess school quality;

- Because teachers, parents, and students become very invested in particular schools, charter authorizers may find destroying a school community more difficult than serving a diffuse public interest; and

- Because charter schools have become a highly politicized issue for both proponents and opponents, some charter authorizers do not want their decisions to reflect poorly on the reform concept of charter schools (Bulkley, 2001).

Both advocates and critics of charter schools recognize these challenges to performance accountability. In practice, one study noted, "Accountability typically means a half-baked version of the top-down regulation-and-compliance system that the state or community applies to its conventional public schools" (Finn, Manno, \& Vanourek, 2000, p. 135).

All states allow charters to be revoked or not renewed for reasons related to educational performance. However, almost all charter schools that have closed (whether of their own accord, revocation, or non-renewal) were closed for reasons unrelated or indirectly related to educational performance (Center for Education Reform, 2000). The most common causes have been "organizational chaos, management meltdown, and fiscal shenanigans" (Finn, Manno, \& Vanourek, 2000, p. 137).
Permitting and requiring educational performance to be a criterion for closing a charter school, therefore, are not the same.

The original rationale for charter schools focused on charter renewal as the primary time for accountability for performance, but some states and charter authorizers are exploring other approaches to assessing quality and holding schools accountable for quality. One recent report discussed different "corrective actions" that have been taken, including placing schools on probation (SRI International, 2000) Another report examined new models of external accountability such as inspectorates in Massachusetts and peer review elsewhere (Hill et al., 2001). Possible accountability "middle ground" (options between no action and school closure) has generally become attractive to charter authorizers. These options include: paying greater attention to applications, having schools explain why achievement may be lower than expected, requiring schools to draw on outside resources (such as financial auditors or accreditation organizations) for technical assistance, or allowing the charter authorizing agency to provide assistance to the schools (Bulkley, 2001).

Many charter-granting agencies have focused primarily on governmental accountability on financial and legal compliance issues, with some monitoring of educational programs and outcomes (mostly through test scores).

\section{Accountability to the Market}

Accountability to the market seems to be operating more closely to the expectations of the originators of the charter school concept. Hill et al. (2001) argued that charter schools concentrate more on accountability to immediate 
stakeholders (that is, teachers, parents, and students) than on accountability to the charter-granting agency. They found that the focus of particular schools was on developing strong internal accountability, "a set of productive and mutually responsible relationships among teachers, administrators, and parents, united on behalf of effective instruction for children" (p. iv). They observed, "The fact that charter schools must maintain relationships of trust and confidence with parents and teachers, as well as to government, motivates the intense internal collaboration that leads to internal accountability" (p. iv). Other studies also found an emphasis on local accountability. Wohlstetter and Griffin (1998) concluded, "Across all the charter schools in our study, the strongest feeling of accountability was to the local school community, especially to parents and students" (p. 17).

Indicators of market satisfaction, including waiting lists and stakeholder satisfaction, support the notion that charter schools are responding to their clients. RPP International (2000) concluded, "The demand for charter schools remains high -7 of 10 charter schools reported that they have a waiting list. This percentage is the same as reported for 1997-1998" (p. 1). This data, however, is available only from schools that chose to report whether or not they had a waiting list; waiting-list size was not reported.

Parents generally give their charter schools positive marks. The RAND review of research found that "parents of children in voucher and charter schools are more satisfied, on a wide variety of dimensions, than are comparison groups of local public school parents" (Gill, Timpane, Ross, \& Brewer, 2001, p. 137). Finn, Manno, and Vanourek (2000) cited survey data (from schools recommended by state personnel) indicating that charters were "extremely popular" among parents. At least two-thirds of the parents rated them superior to their children's previous schools with regard to class size, school size, attention from teachers, quality of instruction, and curriculum. Parents also reported that their children were doing better academically in the charter school. In Minnesota and Texas, $85 \%$ to $90 \%$ of charter school parents (compared with $70 \%$ of public school parents nationally) gave their schools an " $\mathrm{A}$ " or " $\mathrm{B}$ " (Center for Applied Research and Educational Improvement, 1998; Rose \& Gallup, 2000; Texas Education Agency, 2000).

Parents appear to be highly involved in charter schools. Minnesota parents, for example, reported that they were more involved with the charter school than with previous schools (Center for Applied Research and Educational Improvement, 1998). Involvement in areas ranging from classroom support to fundraising to decision-making can be important reasons that parents enroll or keep their child in a particular school. An evaluation of Los Angeles charter schools noted, "While efforts to maintain communication and create an inclusive environment may be common to other schools, many parents interviewed pointed to these elements as crucial to their desire to keep their children in the school" (WestEd \& University of Southern California, 1998, p. 15). Another study suggested that active parent involvement can be a mixed blessing: "In some cases, there was such a high degree of parent involvement that clear parameters and boundaries needed to be established to guide interaction" (WestEd \& University of Southern California, 1998, p. 15). 
An analysis of student satisfaction data showed that overall student satisfaction rates for charter schools were high. Sixty-one percent of charter school students surveyed in Connecticut said they would recommend a charter school to a friend (Horn \& Miron, 1998). Satisfaction rates in some categories were lower, especially for curricular and extracurricular offerings, and for available resources and facilities. Student dislikes generally concerned nonacademic matters such as poor sports programs, not enough other activities, food quality, and too much homework. Students noted lack of financial resources and curricular and extracurricular activities as setbacks for their charter school. A Minnesota report indicated that the satisfaction level of charter school students, when compared to ratings of students across the country, was average to above average for all categories except school activities (Center for Applied Research and Educational Improvement, 1998). Only three charter school features - recreation areas, the cafeteria, and sports or other activities - were liked by fewer Arizona charter school students than liked these features (Mulholland, 1999).

Charter school teachers typically have high satisfaction ratings. A survey of Minnesota charter school teachers showed $81 \%$ to be satisfied or very satisfied and only $6 \%$ dissatisfied or very dissatisfied (Center for Applied Research and Educational Improvement, 1998). These highly positive ratings, it should be noted, were typical among teachers in district-run schools nationally who completed the same survey. Charter school teachers in Connecticut also reported high levels of satisfaction although these levels diminished after the first year (Horn \& Miron, 1998).

California charter school teachers felt positively about their schools, but found teaching there to be an overwhelming experience, which may help explain the high level of teacher turnover in start-up charter schools (Wells, 1998; see also Texas Education Agency, 1999). Wells (1998) noted, "While small charter schools and those able to curtail class size provided deeply satisfying working conditions for the teachers in our study, they also made substantial demands on teachers' time and energy that may be difficult to sustain over time" (p. 52).

A sense of teacher empowerment could serve as another measure of teacher satisfaction. According to Finn, Manno, and Vanourek (2000), "The biggest plus for charter teachers is professional empowerment" (p. 89). A Colorado study by Bomotti, Ginsberg, and Cobb (1999) compared teachers in Colorado charter schools with teachers in district-run public schools. The charter school teachers felt more empowered within their classrooms, but felt less empowered in the schools than did teachers in district-run public schools. The charter school teachers were somewhat more satisfied with their conditions for teaching and learning, but less satisfied with the physical plant and the support they received in their schools.

Overall, market-based accountability seems to be operating roughly as advocates anticipated, while the role of government in ensuring school quality through applications, monitoring, and renewal is less clear and more varied across charter authorizers and states. Key questions about accountability that merit further exploration include:

- What policies appear to promote strong internal accountability? 
- What methods are schools and charter authorizing agencies using to align internal and external accountability so that strong internal accountability is consistent with the responsibilities of charter schools as public institutions?

- What alternative approaches are charter school authorizers and other government agencies using to find a middle ground between allowing a school to continue operating unchanged, even if it is not meeting expectations, or closing it down? What are the implications of these alternatives for school quality and autonomy?

- What is the impact of for-profit management companies on governmental accountability?

\section{Are Charter Schools Equitable?}

The equity issues affecting charter schools include racial composition of student enrollment, provision of services for students with special needs, recruitment and admission practices, and resource availability for schools serving different student populations. Equity issues can create tension for charter schools: they are expected to be focused and mission-driven in order to be innovative and effective, and at the same time, they are required to serve all students.

\section{Racial and Socioeconomic Composition}

Charter schools, like other schools of choice, have the "...potential to further stratify schools along racial, socioeconomic, and other class-based lines" (Cobb \& Glass, 1999, p. 2) or to engage in various forms of "social sorting" (Arsen, Plank, \& Sykes, 1999). These patterns may result from parents' choosing schools that reflect their ethnic or racial background, from schools' focusing their curriculum on a particular culture or theme, or from schools' recruiting students primarily in particular venues.

A recent national study suggests that, overall, the racial composition of students enrolled in charter schools was similar to that of their local public school districts. Nearly $70 \%$ of charter schools had a student racial and ethnic composition similar to the surrounding school district, about $17 \%$ of charter schools served a higher proportion of students of color, and about $14 \%$ enrolled a lower percentage of students of color (RPP International, 2000). ${ }^{5}$ The researchers found: "Overall, charter schools enrolled a larger percentage of students of color than all public schools in the states with open charter schools. Over the last three years, the percentage of White students served by charter schools has slightly declined. At the local level, most charter schools had about the same proportion of White students (within 20\%) as their surrounding districts" (RPP International, 2000, p. 1).

There are, however, charter schools that have significantly different racial and ethnic populations than traditional public schools in the same area. The most elaborate state study of racial and ethnic enrollments was conducted in Arizona,

\footnotetext{
${ }^{5}$ The researchers defined "not distinct"(meaning similar) if the charter school's composition was within $20 \%$ of the district average. Hypothetically speaking, this would mean that an essentially homogenous charter school (say, 95\% White) located within a district having one-fourth minority enrollment would be considered "not distinct."
} 
which is an atypical charter school state in several ways. This study used a mapping technique to compare the racial makeup of charter schools with nearby public schools. The Arizona study found that a substantial number of charter schools differed from their neighboring public schools, often because they had a significantly higher proportion of White students (Cobb \& Glass, 1999). The degree of ethnic separation, the authors argued, was large and consistent enough to "warrant concern among education policymakers" (Cobb \& Glass, 1999, p. 2).

Michigan charter schools serve a significantly higher minority population than district-run public schools in the state (Public Sector Consultants \& MAXIMUS, 1999). Sixty-nine percent of Michigan charter students are African American, as compared with $14 \%$ percent of the general Michigan population. However, more than half of Michigan charter schools are located in Detroit which has a higher percentage of African Americans than the rest of the state. Individual charter schools in Michigan serve a higher percentage of minority students than their surrounding school districts; on average, Michigan charter schools have $66 \%$ minority enrollment compared to $54 \%$ in their host school districts. Similar findings emerged from studies in Connecticut and Pennsylvania (Horn \& Miron, 1998; Miron \& Nelson, 2000). These findings reflect a trend in some states toward concentrations of charter schools in urban areas. These studies often compare an aggregate of charter school students with statewide averages, but future research should follow the work of Cobb and Glass in comparing racial composition on a school-by-school basis.

Future research should also examine which schools are serving which students. In Texas, charter schools are designated as at-risk or non-at-risk. A valuable study found that the at-risk charter schools served much higher concentrations of minority students and lower concentrations of Anglo students than traditional Texas public schools. The non-at-risk schools served lower percentages of Hispanic students and higher percentages of African American and Anglo students than traditional Texas public schools (Texas Education Agency, 2000).

Existing studies have tended to look at whether or not charter schools are racially distinct from public schools. But, because existing public schools are often relatively segregated, research should also examine overall levels of integration in district-run public schools and in charter schools. One recent study argued that "the effect of choice on integration should be assessed by comparing the racial composition of individual schools to the racial composition of the broader community in which schools are located," rather than to the racial composition of public schools in those communities (Greene, 2000). Discussions of racial composition have not adequately addressed the broader issue of whether the less-integrated schools (especially those serving a predominantly minority population) are inherently problematic if parents are choosing them and the schools are demonstrating that they provide quality education.

In terms of family income, charter schools nationally served a proportion of students eligible for federal free or reduced-price lunch programs similar to district-operated public schools (RPP International, 2000). In some states, however, the proportion of low-income students enrolled in charter schools was 
higher than the state average, while in other states the proportion was lower.

\section{Special Education}

A recent national study suggests that a slightly smaller percentage of students with disabilities are enrolled in charter schools ( $8 \%)$ than in district-operated public schools (11\%) (RPP International, 2000). Thirty percent of charter schools in a California study reported that being unable to meet a student's special needs could justify not admitting that student (SRI International, 1997). Another study concluded that charter schools enrolled a higher percentage of students with special needs than district-run public schools (Finn, Manno, \& Vanourek, 2000). The numbers from this study, however, included students who had Individualized Education Plans (IEPs) as well as students "...who do not now have an IEP but probably would have at conventional public schools" and "other students with serious learning impediments" ( Finn, Manno, \& Vanourek, 2000, p. 81). These different ways of calculating the extent to which charter schools serve special needs students makes comparisons difficult (Finn, Manno, \& Vanourek, 2000).

An important national study of special education in charter schools found that parents were enrolling children with "mild disabilities" in charter schools, but rarely enrolling children with more significant disabilities (unless the school was designed for such students) (Fiore et al., 2000). The study also found that charter school staff, at times, "counsel" some parents of students with disabilities and discourage them from enrolling their child at the charter school. Challenges for parents and students with disabilities have included understanding their rights and obtaining adequate funding and specialized services (see also Nelson, Muir, \& Drown, 2000). Still, Fiore et al. (2000) found that "[b]y almost all

accounts, students with and without disabilities receive more individualized attention at the charter school than they did at their previous school" (p. 41).

\section{Admissions}

The admissions and recruitment practices of charter schools have been raised as another potential challenge to equity. Charter schools in most states are legally required to be open to all students and, if they accept federal Public Charter School Program funds, charter schools must accept students based on a lottery. But, the way a charter school advertises and the requirements it imposes (such as parental involvement contracts) may effectively narrow the range of students seeking admission. In addition, if charter schools recruit students primarily by word-of-mouth, there may be equity issues of homogeneity and access (see Cobb \& Glass, 1999).

One of the most critical studies of charter school admissions looked at 17 California charter schools and concluded, "Through various mechanisms such as enrollment, recruitment, and requirements, charter schools have more power than most public schools to shape their school communities" (Wells, 1998, p. 42). Wells argued that students could be steered away from a particular school through targeted recruitment, mandatory parental involvement, and standards for applicants' prior behavior or academic success. Arsen, Plank, and Sykes (1999) also raised questions about admissions practices. They found that some Michigan charter schools had application procedures, application forms, and interviews that made it "at least possible for administrators to discourage 
applications from students who might disrupt the school community" (p. 75). Similarly, Fuller (2000) argued that charters may "invite" families with particular similarities or shared interests to participate.

Despite early concerns, there was little or no evidence that charter schools were pulling the most successful students or wealthiest students from the district-run public education system. Charter schools, however, may be drawing some of the most involved families from district-run public schools. Evidence that this "creaming" does or does not exist is sometimes hard to interpret, because an important aspect of assessing creaming is comparing charter schools to proximate district-run public schools, rather than to state averages.

Eighty percent of Massachusetts charter schools that opened in 1995 enrolled students that performed at average or below average academic levels (Massachusetts Department of Education, 1997). SRI International (1997) reported that, on average, low-achieving students accounted for $41 \%$ of California charter school students. Charter school students in Minnesota and Pennsylvania were similarly found to have average to belowaverage levels of academic achievement (Center for Applied Research and Educational Improvement, 1998; Miron \& Nelson, 2000).

Drawing students from higher income families would be another form of creaming. Most information available at this time aggregates data across charter schools. A slightly higher percentage of students eligible for free or reduced-price lunch were served by charter schools (39\%) in 1998-1999 than by all public schools (37\%) in the 27 charter states in 1994-1995 (RPP International, 2000). A study of Washington, DC charter schools found that "for those who fear that charters will cater to an already-favored elite, the evidence from DC to date is generally reassuring" (Henig et al., 1999, p. ii). A Colorado evaluation, however, found that $19.4 \%$ of charter school students were eligible for free or reducedprice lunch, while the state average was $27.7 \%$ (Fitzgerald, 2000). Miron and Nelson (2000) found that Pennsylvania charter schools had a higher percentage of students eligible for free or reducedprice lunch than the schools in their host districts.

\section{Financing}

Another area of equity concern has been the relationship between the financial status of a charter school and the socioeconomic status of its students. One California study found negative implications for equity in that charter schools often needed to raise private funds and their ability to do so could be influenced by the social class of their students (Wells, 1998). The author questioned "...the argument that charter schools, freed from bureaucratic constraints, will be more efficient and require less funding...We find this claim to be misleading. Instead, we found charter schools' very fiscal survival often depends on their ability to acquire extra private funds" (p. 35). Wells continued, "Generally speaking, schools located in predominantly middle- and uppermiddle-class communities (those generally serving a higher proportion of White students) tended to have easier access to financial and in-kind resources due to their connections" (p. 38). It is unclear from this study if this situation is similarly experienced by district-run public schools in more versus less affluent areas. In addition, there have been charter schools serving high 
percentages of poor, minority students that have been able to raise considerable private funding. Moreover, according to the one national finance study of charter schools, "A majority of states provide additional funding to charter schools for at-risk students either directly, or through school district negotiations" (Nelson, Muir, \& Drown, 2000, p. 2).

Issues of equity are a critical area for future charter schools research. Questions about student admissions and recruitment and possible steering of students and parents to and from particular schools must be carefully studied. Researchers must consider which students are served by charter schools and how they are being served. The role of financing - both public and private - is an integral part of charter school equity.

\section{Are Charter Schools Leading to Educational Improvement?}

Charter school advocates believed that charter school laws would ultimately lead to a variety of desirable outcomes: improved student achievement, improved student learning, improvement in district-run public schools as they responded to the new competition, and greater parent, student, and teacher satisfaction (Kolderie, 1990). What evidence is there to document any of these improvements?

\section{Student Achievement}

Tracking the impact of charter schools on student performance is, to say the least, difficult; most charters are relatively new; by definition, charters are quite varied in their approaches and educational goals; a variety of assessment instruments are used; and data are not always easily obtained (SRI

International, 1997, p. 15).

Student achievement data are an important and agreed-upon component of charter school accountability. A focus on academic achievement of students is common among charter school mission statements (Horn \& Miron, 1998, p. 10). Charter school advocates argue that there is strong evidence of success in this area, but a closer examination of the research reveals a more complicated picture. Unfortunately, the preliminary evidence on student achievement in charter schools is limited and far from definitive. We examined more than 25 charter school evaluation reports written between 1997 and 2001; these reports constitute the data source for this analysis of student achievement. There are, however, a number of problems with the available data. This section of our paper first outlines some major problems in obtaining and interpreting student achievement data for charter schools, and then summarizes some findings in different states.

\section{Limitations of Student Achievement Data}

Many of the evaluation reports we examined were written when most charter schools had been operating for only one-to-three years. The newness of the charter schools is the source of several problems related to gathering and analyzing student achievement data. In their first few years, many charter schools focus on becoming viable organizations - finding facilities, getting resources, organizing curriculum, and establishing teachers and leadership. Additionally, there is generally a decline in test scores when students change schools, an effect that would confound the results of early 
studies of student achievement in charter schools (Solmon, Paark, \& Garcia, 2001). The newness of the charter reform itself means there is a scarcity of adequate achievement data. Longitudinal data are preferable to point-in-time data, but adequate longitudinal data are not yet available because most charter schools have been operating for an insufficient period of time.

In addition, charter schools frequently enroll students who encountered difficulty and even failure in previous educational arenas, making it unfair to judge charter schools early based on achievement scores. Specific charter schools may be serving a higher number of low-achieving and at-risk students than district-run schools. As noted above, $80 \%$ of the charter schools that opened in Massachusetts in 1995 enrolled students performing at or below average academically (Massachusetts Department of Education, 1997) (see also Clayton Foundation, 1999; SRI International, 1997).

Conclusions about current achievement levels are additionally confounded by the role of students' prior educational experience. The report, "Charter Schools: A Look at Accountability," noted that few charter laws required reporting of systematic baseline data on the academic achievement of students prior to their enrollment in charter schools (National Education Association, 1998). Lack of baseline data makes it difficult to determine whether charter school students are making improvements over their past school achievement. Current achievement data that are available for charter schools, at best, serve as baseline information about the level of students enrolling in charter schools, but not as measures of success in improving student learning. Longitudinal data over multiple years are needed to adequately address the issue of student improvement (Solmon, Paark, \& Garcia, 2001). It will take time for even the most effective charter schools to significantly improve student achievement, especially among low-achieving, at-risk students. There is the added difficulty, once longitudinal data are available, of drawing equitable comparisons between student achievement in charter schools and in other public schools, a task required by some states (Illinois State Board of Education, 1999; Miron \& Nelson, 2000). Among reasons for this difficulty is the impact of self-selection on student achievement (Fuller, 2000; Miron \& Nelson, 2000; Solmon, Paark, \& Garcia, 2001).

It is difficult to analyze and make comparisons between schools that use alternative assessment measures because definitions of these measures and indications of progress vary significantly. Without standardized quantitative data, anecdotal evidence has become a widespread method of demonstrating educational outcomes (Center for Education Reform, 2000; Finn, Manno, \& Vanourek, 2000), making it difficult to draw objective, standardized conclusions about academic achievement in charter schools.

Even where quantitative data from standardized tests are available, the manner in which these data are reported presents problems. Data are rarely available on the student level; a notable exception is the Arizona report by Solmon, Paark, and Garcia (2001). Student-level data would allow researchers to overcome the difficulty of dealing with unstable charter school populations. Because charter schools often experience significant student 
turnover (in part because many serve transient and difficult-to-retain populations), comparisons from one year to the next using point-in-time data are precarious. The 1997 Massachusetts charter school report warns that sample sizes in schools and grades were so small that even small changes in a school's composition could result in substantial changes in test results. Results, therefore, must be judged with great caution (Massachusetts Department of Education, 1997). Longitudinal, student-level data would help to alleviate this problem, but most charter schools have not been open long enough. Further, longitudinal analysis will continue to be problematic in cases where students are not tested in every grade (Miron, 2000).

Charter schools often serve populations that are distinct (both in objective characteristics and in terms of self-selection) from those of the sponsoring district, which presents another challenge. Finding appropriate comparison district-run schools has not been a simple task. Comparisons among charter schools, between charters and other public schools, and between states would be easier if there was a consensus as how best to measure student achievement. Such a consensus, however, seems unlikely and is not necessarily desirable or consistent with the ideals of charter schools. As noted in one Colorado evaluation, "The diversity and autonomy that the Charter Schools Act was intended to promote is incompatible with the standardization required to support direct comparisons" (Fitzgerald, 2000, p. xi).

Standardized tests offer the most efficient means for making comparisons between schools. However, as noted by one study:
Problems with using standardized tests include the argument that these tests emphasize product over process, rely on artificial testing situations, and correlate to strong test-taking skills rather than actual student learning. Furthermore, a variety of tests are in use and although NCEs [normal curve equivalents] allow for cross-test comparisons, it can be argued that different tests may not address the same constructs (SRI International, 1997).

Different schools use different tests, and while the reporting of normal curve equivalents does allow for comparisons across different instruments, few schools have or report these data. Moreover, achievement data from some especially small charter schools are not available to researchers because of concerns about student confidentiality.

Most charter schools do use standardized tests, but few rely solely on these tests to evaluate or report student achievement. Charter schools are supposed to be innovative and nontraditional in their approach to education. Therefore, most charter schools argue that standardized tests do not fully capture all the educational outcomes that are important. Others have argued that standardized tests unfairly assess particular populations of students. For example, some have criticized Michigan's assessment test on the grounds that it is culturally biased and fails to measure some central objectives of charter schools. These unmeasured objectives include character development, vocational skills, fine arts, and knowledge of a specific culture or ethnic group (Public Sector Consultants \& MAXIMUS, 1999, p. 60).

Finally, there is considerable variation in charter schools from state-to-state and district-to-district. This variance makes accurate generalizations about charter 
schools difficult, if not impossible, to make. Any analysis of student achievement in charter schools must take this variance into account; generalizations must be tempered with a discussion of the extremes that exist at both ends of the continuum. As the authors of one study argued, "The reader must keep in mind that just as there is no single Michigan charter school model, there is no single statement that may be made about all charter schools and student achievement" (Public Sector Consultants \& MAXIMUS, 1999, p. 61).

\section{Achievement Data}

Keeping in mind all of the caveats just described, we reviewed 25 reports that included information on student achievement in charter schools. Several studies suggest that some charter schools were seeing gains in student achievement. One study from the Center for School Change asked officials in nine states to nominate three-to-five charter schools in their state that "have a welldeveloped evaluation system and have been successful in improving student achievement" (Cheung, Murphy, \& Nathan, 1998, p. 8). Therefore, the schools in this study were not a representative random sample of charter schools, and it was not surprising that they found examples of charter schools showing achievement gains. Colorado reported favorable test results for charter schools. This report included data from Colorado's 51 charter schools that had been open for at least two years at the end of the 1998-1999 school year. The Colorado charter schools in this study "...outperformed both the state and their authorizing districts. The charter schools also outperformed other public schools with student populations of the same general socioeconomic level" (Fitzgerald, 2000, p. xi).
An analysis of achievement data from the Los Angeles Unified District found that charter schools that began with high average scores maintained high scores over time. The analysis also found that schools that began with very low average scores generally showed improvement comparable to, and sometimes stronger than, comparison schools (WestEd \& University of Southern California, 1998).

One Arizona study incorporated relatively complex statistical analyses of longitudinal achievement test scores (1997, 1998, and 1999) from the Stanford Achievement Test (SAT-9) for both charter and district-run public schools (Solmon, Paark, \& Garcia, 2001). The analyses included strategies to control for initial school of attendance (charter or district-run public school), race, years in district, days absent, primary languages, gifted or special education status, and grade level. Solmon, Paark, and Garcia (2001) concluded, "Students enrolled in charter schools for two and three consecutive years have an advantage [in reading] over students staying in districtrun public schools for the same periods of time" (p. 4). In math, charter school students had a slight advantage over their peers in district-run public schools, but an "insignificantly lower gain" after three years.

There are also examples of available achievement data that do not look especially promising for charter schools. In Washington, DC, more than $75 \%$ of students in 7 of the district's 16 charter schools scored below basic in math and reading. In comparison with the mixed results of the district-run public schools in Washington, DC, the students enrolled in the charter schools were not achieving at higher standards. Researchers cautioned against premature conclusions, however, because there has been very limited 
research conducted on the public school test results (Henig et al., 1999).

The achievement data from charter schools are largely mixed. One Michigan study found that charter schools had significantly lower state test scores and lower two- and three-year test score gains than their host districts (Horn \& Miron, 1999). But some Michigan charter schools had higher test scores, at least at some grade levels. Another Michigan study used an Annual Yearly Progress analysis to show that more charter schools $(83 \%$ in math; $63 \%$ in reading) than comparison schools (58\% in math; $46 \%$ in reading) achieved their target gains in 1997-1998 (Public Sector Consultants \& MAXIMUS, 1999). Charter schools had more success particularly in moving students from low to moderate achievement groups.

A recent study of Pennsylvania charter schools also found mixed achievement outcomes. Average charter school scores on the Pennsylvania assessment were 140 points lower than average scores for district-run public schools, although the difference was smaller when charter schools were compared to their host districts (Miron \& Nelson, 2000). There were, however, several charter schools that outperformed district-run schools and their host districts. The researchers used a regression model to predict test scores based on concentrations of low-income students in each school. In this analysis, charter schools scored an average 46 points lower than district-run public schools, but some charter schools scored higher than predicted. An analysis of change scores (in which each school serves as its own comparison group) showed that charter schools improved an average of 86 points more than their host districts. But the analysis was based on a very small sample of four schools and compared two different groups of students (that is, fifth-grade students in 1997-1998 with fifth-grade students in 1998-1999).

The 1997-1998 evaluation of the first 19 open-enrollment charter schools in Texas (the majority of which were established to serve students at risk of dropping out) reported that the charter school students performed at lower levels than students in district-run public schools (Texas Education Agency, 1999). Forty percent of charter schools in Texas had an acceptable or higher rating as compared with $91 \%$ of district-run public schools. The Texas report also noted that three charter schools outperformed the state average, one of which achieved a recognized rating (Texas Education Agency, 1999).

According to a 1997 report by the Massachusetts Department of Education, six of the eight charter schools for which adequate test data were available "appear[ed] to be making academic progress." Progress in the other two charter schools was unclear because of limitations in the data. A 1999 report on 13 Illinois charter schools also presented a mixed review: some charter schools were doing better than similar grades in their host school district, but others were doing worse. Researchers were unable to draw a comprehensive conclusion about charter school achievement (Illinois State Board of Education, 1999).

Overall, there are no conclusive data to indicate that charter schools on the whole are failing their students, and some charter schools are showing positive achievement results. A recent review of student achievement in charter schools by RAND researchers concluded that the "evidence on the academic effectiveness of charter schools is mixed" (Gill et al., 
2001, p. 95). Future research on student achievement is needed to look beyond aggregate test scores to focus on why students in some schools show greater achievement gains than in others. As Gill et al. (2001) argued, "These charter school evaluations...have been black boxes, making no attempt to explain the reasons for any measured effects on student achievement. Getting inside the black box is especially important, because charter schools (like private schools) are by their nature diverse" (p. 96). Longitudinal, student-level data from agreed-upon measures of achievement are the most desirable for drawing conclusions about charter school achievement. This kind of information is difficult to acquire for many of the reasons outlined above. As the charter school movement matures, however, the quality and quantity of achievement data must improve as well.

\section{Systemic Effects}

Advocates expected that charter schools would lead to a "ripple effect" in which districts would "...change and improve their systems in response to the appearance of charter laws and charter schools" (RPP International, 2001, p. 5). The ripple effect would be the result of the need to compete with charter schools for students, and of the ability to borrow educational ideas from local charter schools. Charter school proponents also expected that this effect would be mediated by tensions between charter schools and districts. Several studies have noted evidence of such tensions (Henig et al., 1999; Horn \& Miron, 1998; Rofes, 1998). Any examination of systemic effects of charter schools is limited by the national context in which only a few states have more than $2 \%$ of their public student population enrolled in charter schools, although individual districts in some states have a much higher percentage (RPP International, 2000).

The impact of charter schools on local districts and district schools has been a focus of studies by Rofes (1998) and by RPP International (2001). Both Rofes and RPP International examined how (and if) districts altered various behaviors in response to the presence of charter schools. Rofes found considerable variation across districts in his examination of 25 districts in eight states and the District of Columbia, but concluded, "Typically, school districts had not responded with swift, dramatic improvements at the time of this study" (p. 2). He reported that "the majority of districts had gone about business-asusual and responded to charters slowly and in small ways" (p. 11). Increased marketing and public relations efforts were common responses to the presence of charter schools. Some districts created schools focused on specific philosophies or themes similar to charter schools (for example, back-to-basics schools) and added programs such as all-day kindergarten and after-school programs. Rofes found that teachers in some districts felt more pressure to produce strong educational results because of the presence of charter schools.

Other studies found little evidence of district change in response to competition from charter schools. Arsen, Plank, and Sykes (1999) suggested that such changes were unlikely until districts begin to examine why their parents are defecting to charters (See also Teske, Schneider, Buckley, \& Clare, 2000). Competition may put charter schools at odds with districtrun public schools; Wells (1998) observed that borrowing ideas requires a more collaborative relationship. Texas superintendents were surveyed as part of a state-conducted evaluation. Ninety-five 
percent of the Texas superintendents reported that there had been no changes in educational policies, programs, or services as a result of charter schools in their areas. Not one superintendent said that a school in his or her district had adopted practices similar to those in a local charter school (Texas Education Agency, 2000).

Using a broader definition of systemic effects, RPP International found some response to the charter schools in all 49 districts they studied. The most common effects reported by administrators and local journalists included: changing central office operations (such as tracking students who left for or returned from charter schools); comparing achievement of students in district schools with those enrolled in charter schools; and seeking to improve customer service, marketing, and parental outreach. District administrators, in some cases, perceived decreased budgets as a negative effect of charter schools. Administrators also thought charter schools were more likely to negatively influence the district if they had not been authorized by the district, and if district enrollments were dropping. Two other studies found examples of districts changing in response to the charter schools, but both studies relied heavily on anecdotal information, not on the systematic information necessary to establish some confidence of causality (Center for Education Reform, 2000; Finn, Manno, \& Vanourek, 2000).

Under the category of borrowing educational ideas from charter schools, RPP International (2001) found that roughly half of the districts they studied had created at least one new educational program (such as extended kindergarten programs or new specialized classes) as a result of the charter schools. Rofes (1998), however, reported that district personnel seldom saw or used charter schools as laboratories for educational innovations. He argued that, for this to happen, charter schools would have to be producing new knowledge and districts would have to be open to using that knowledge in their schools. Wells (1998) found in California "few direct effects of charter schools on the ways in which nearby public schools operated and educated children" (p. 54). Wells saw little direct communication between charter schools and other public schools in the 10 districts studied, thus making it "...difficult to imagine how charter schools will serve as laboratories for public systems" (p. 55). These seemingly contradictory findings about borrowing ideas from charter schools are explained by a difference in emphasis: Rofes and Wells looked for new knowledge, while RPP International focused on new programs that might draw on preexisting knowledge.

A study of school districts with multiple charter schools in New Jersey, Massachusetts, and the District of Columbia found that entrepreneurial and reform-oriented administrators used charter schools "... as a tool to increase their leverage over their schools and force them to institute new programs and improve performance" (Teske et al., p. 9). RPP International (2001) found “... a handful of districts [that] used charter schools as a tool to promote educational reform in their district" (p. 3). Regardless of the transfer of practices from charter schools to traditional public schools, both the study by Rofes (1998) and the study by Finn, Manno, and Vanourek (2000) suggest that school districts with charter schools in their regions generally become more accepting (if they were not initially) of the charter schools over time. 
Many, but not all, districts with multiple charter schools nearby appear to be responding to the changing landscape of public education offerings. The changes made by public school districts generally include adding programs, increasing marketing, and becoming more responsive to parents. These changes (with the possible exception of greater responsiveness to parents) represent just intermediate steps toward improving the quality of the education in district-run public schools.

Without further research, it is impossible to know if these changes will lead to improved school quality or student outcomes. The RPP International study (2001) "does not attempt to determine if changes made by districts represent what is 'good' or 'bad' from the perspective of the larger educational system" (p. 9). Only Bettinger's Michigan study (1999) attempted to assess the impact of charter schools on student achievement in neighboring district-run public schools. Bettinger found no evidence to suggest that public school test scores were increasing as a result of competition; he did find some preliminary evidence to suggest that district-run public schools near charter schools may see decreasing scores. He emphasizes, however, "The short-run effects may differ substantially from the long-run equilibrium with charter schools" (p. 21).

\section{Conclusion and Policy Implications}

Some questions about charter schools can be answered more easily than others. The evidence, for example, is strong that parents and students enrolled in charter schools are satisfied with their experiences. It is clear that charter schools are more autonomous than district-run public schools, although the level of autonomy varies considerably. But research is only beginning to illuminate some of the most important questions about innovation, accountability, equity, and outcomes.

\section{Innovation}

While charter schools are not always innovative in that they offer something new, they do look different from districtrun public schools in such areas as their management and organization. It is unclear, however, if and when such differences translate into changed classroom practice or student achievement. Future research is needed to explore the educational experiences of students in charter schools and, regardless of innovation, examine the quality of schooling and the policy levers that promote high-quality charter schools. Policymakers should focus on school quality, which is more likely than innovation to yield the positive educational results envisioned by charter school advocates. Using sophisticated indepth methods to examine teaching and learning, the research should concentrate on where improved instruction and achievement are occurring. Charter schools that provide high-quality instruction can be studied to identify institutional and political structures that promote these developments.

\section{Accountability}

The market side of the charter school accountability equation is operating far more consistently and predictably than the government side. Charter schools see a strong need to consider consumer preferences, but do not always see (or even understand) a strong need to respond to government performance 
demands. Of particular concern is the use of school closure as an accountability tool. Charter school authorizing agencies have found closure to be problematic, and some agencies have sought ways of supporting and improving charter schools instead of closing them. Policymakers should reconsider the proper role of government in charter school accountability; they may want to modify current statutes to reconfigure government's role and renewal as the primary mechanism for governmental accountability. Researchers should look at how authorizing agencies are supporting and critiquing charter schools to promote quality education, because these agencies seem generally unwilling to close them.

\section{Equity}

Equity issues are critical if charter schools are to serve the public interest as well as the private preferences of parents and students. These issues include admissions and recruitment practices, the potential for increased segregation, and monitoring of special education services by policymakers. Current evidence suggests that the greatest fears of charter school critics - such as creaming of top students or radical re-segregation - are not occurring (at least on a broad scale). Evidence from Arizona, however, suggests that some charter schools are racially distinct from neighboring public schools. Anecdotal evidence also suggests that, even when charter schools use lotteries in admissions, some schools may use targeted recruitment, mandatory parental involvement policies, and applicants' prior records to discourage students they do not want to enroll. Special education has been a particular challenge for charter schools, and continued attention to this issue is extremely important. Equity issues present a critical area for future research: charter school practices should be scrutinized to determine whether they advance or reverse equity in public education. Most analyses up to now have focused primarily on which students the charter schools are serving. Ongoing examination of the student population is necessary, but future study should also consider how charter schools are serving students with diverse needs.

\section{Outcomes}

Overall, information on charter school outcomes suggests a wait-and-see approach. Additional research is needed to determine why some schools are performing far better than others. Development of richer ways of measuring the education offered by diverse charter schools will be critical to balancing the public and private interests in these schools, and in determining how the varied schools can serve the entire range of stakeholders - parents, students, and staff, but also government and the general public.

In terms of systemic change, it seems likely that long-term and sustained influences on the broader system will emerge very slowly. The adaptations that some districts are making in response to charter schools are important, but any effects on the quality of district-run public schools are largely unknown. The positive and negative impact of charter schools on the broader education system is easily ignored, but is critical to a real understanding of the value of this reform concept. 
Charter schools have created considerable excitement and, at times, an understandable level of tension in public education nationally. As the number of charter schools grows over time, continued research is needed to shed light on how this reform can advance the overall goal of improving education. 


\section{References}

Arsen, D., Plank, D., \& Sykes, G. (1999). School choice policies in Michigan:

The rules matter. East Lansing, MI: Center on School Choice and Educational Change, Michigan State University.

Ascher, C., Jacobowitz, R., McBride, Y., \& Wamba, N. (2000). Reflections from New York City's charter schools and charter authorizers. New York: Institute for Education and Social Policy, New York University.

Bettinger, E. (1999). The effect of charter schools on charter students and public schools (Occasional Paper No. 4). New York: National Center for the Study of Privatization in Education, Teachers College, Columbia University.

Bomotti, S., Ginsberg, R., \& Cobb, B. (1999). Teachers in charter schools and traditional schools: A comparative study. Education Policy Analysis Archives, 7(22), http:/ / epaa.asu.edu/epaa/v7n22.html.

Budde, R. (1988). Education by charter: Restructuring school districts. Andover, MA: Regional Laboratory for Educational Improvement of the Northeast and Islands.

Buechler, M. (1996). Charter schools: Legislation and results after four years (PRB13). Bloomington, IN: Indiana Education Policy Center.

Bulkley, K. (1999). Charter school authorizers: A new governance mechanism? Educational Policy, 13(5), 674697.

Bulkley, K. (2001). Educational performance and charter school authorizers: The accountability bind.
Education Policy Analysis Archives, 9(37), http:/ /epaa.asu.edu/epaa/v9n37.html.

Center for Applied Research and Educational Improvement. (1998). Minnesota charter schools evaluation. Minneapolis: Author, University of Minnesota.

Center for Education Reform. (2000). Charter schools today: Changing the face of American education. Washington, DC: Author.

Cheung, S., Murphy, M. E., \& Nathan, J. (1998). Making a difference? Charter schools, evaluation, and student performance. Minneapolis: Center for School Change, University of Minnesota.

Clayton Foundation. (1999). 1998 Colorado charter schools evaluation study. Denver: Colorado Department of Education.

Cobb, C. D., \& Glass, G. V. (1999). Ethnic segregation in Arizona charter schools. Education Policy Analysis Archives, 7(1), http:/ /epaa.asu.edu/epaa/v7n1/.

Finn, C. E., Manno, B. V., \& Vanourek, G. (2000). Charter schools in action: Renewing public education. Princeton, NJ: Princeton University Press.

Fiore, T., Harwell, L. M., Blackorby, J., \& Finnigan, K. S. (2000). Charter schools and students with disabilities: A national study. Washington, DC: Office of Educational Research and Improvement, U.S. Department of Education.

Fitzgerald, J. (2000). 1998-1999 Colorado charter schools evaluation study. Denver: Colorado Department of Education. 
Fuller, B. (2000). The public square, big or small? Charter schools in political context. In B. Fuller (Ed.), Inside charter schools: The paradox of radical decentralization. Cambridge, MA: Harvard University Press.

Gill, B. P., Timpane, P. M., Ross, K. E., \& Brewer, D. J. (2001). Rhetoric versus reality: What we know and what we need to know about vouchers and charter schools. Santa Monica, CA: RAND.

Greene, J. P. (2000). Choosing integration. New York: National Center for the Study of Privatization in Education, Teachers College, Columbia University.

Hannaway, J. (1999). Contracting as a mechanism for managing education services (Policy Brief No. RB-28). Philadelphia: Consortium for Policy Research in Education, University of Pennsylvania.

Hassel, B. C. (1999). The charter school challenge: Avoiding the pitfalls, fulfilling the promise. Washington, DC: The Brookings Institution.

Henig, J. R., Moser, M., Holyoke, T. T., \& Lacireno-Paquet, N. (1999). Making a choice, making a difference? An evaluation of charter schools in the District of Columbia. Washington, DC: Center for Washington Area Studies, George Washington University.

Hill, P., Lake, R., Celio, M. B., Campell, C., Herdman, P., \& Bulkley, K. (2001). A study of charter school accountability. Seattle: Center on Reinventing Public Education, University of Washington.

Horn, J., \& Miron, G. (1998). First annual report of the evaluation of the charter schools and the charter school initiative in the state of Connecticut. Kalamazoo, MI: The Evaluation Center, Western Michigan University.

Horn, J., \& Miron, G. (1999). Evaluation of the Michigan Public School Academy initiative. Kalamazoo, MI: The Evaluation Center, Western Michigan University.

Illinois State Board of Education. (1999). Illinois charter school annual report 1998-1999. Springfield, IL: Author.

Kolderie, T. (1990). Beyond choice to new public schools: Withdrawing the exclusive franchise in public education (8). Washington, DC: Progressive Policy Institute.

Kolderie, T. (1998, February). What does it mean to ask: Is 'charter schools' working? http://www.charterfriends. org/working.html.

Koppich, J., Holmes, P., \& Plecki, M. L. (1998). New roles, new rules? The professional work lives of charter school teachers. Washington, DC: Center for the Advancement of Public Education, National Education Association.

Lake, R. J., \& Millot, M. D. (1998). Accountability for charter schools: A comparative assessment of charter school laws. Seattle: Center on Reinventing Public Education.

Massachusetts Department of Education. (1997). 1997 test results from Massachusetts charter schools. Boston: Author.

Mintrom, M. (2000). Leveraging local innovation: The case of Michigan's charter schools. East Lansing, MI: Michigan State University. 
Miron, G. (2000). The initial study of Pennsylvania charter schools: First annual report. Kalamazoo, MI: The Evaluation Center, Western Michigan University.

Miron, G., \& Nelson, C. (2000). Autonomy in exchange for accountability: $A n$ initial study of Pennsylvania charter schools. Kalamazoo, MI: The Evaluation Center, Western Michigan University.

Molnar, A. (2001). Calculating the benefits and costs of for-profit public education. Education Policy Analysis Archives, 9(15), http:/ / epaa.asu.edu/ epaa/v9n15.html

Mulholland, L. A. (1999). Arizona charter school progress evaluation. Tempe, AZ: Morrison Institute for Public Policy, Arizona State University.

Nathan, J. (1996). Charter schools: Creating hope and opportunity for American education. San Francisco: Jossey-Bass.

National Education Association. (1998). Charter schools: A look at accountability. http://www.nea.org/ issues/charter/ accnt98.html.

Nelson, H., Muir, E., and Drown, R. (2000). Venturesome capital: State charter school finance systems. Washington, DC: U.S. Government Printing Office.

Public Sector Consultants \& MAXIMUS. (1999). Michigan's charter school initiative: From theory to practice. Lansing, MI: Author.

Rofes, E. (1998). How are school districts responding to charter school laws and charter schools? Berkeley, CA: Policy Analysis for California Education, University of California-Berkeley.
Rose, L., \& Gallup, A. (2000). The 32nd annual Phi Delta Kappa/Gallup Poll. Phi Delta Kappan, 82(1), 41-58.

Rosenblum Brigham Associates. (1998). Innovation and Massachusetts charter schools. Boston: Author.

RPP International. (1998). A national study of charter schools: Second-year report. Washington, DC: Office of Educational Research and Improvement., U.S. Department of Education.

RPP International. (1999). The state of charter schools, third-year report: National study of charter schools. Washington, DC: Office of Educational Research and Improvement, U.S. Department of Education.

RPP International. (2000). The state of charter schools: 2000. Washington, DC: Office of Educational Research and Improvement, U.S. Department of Education.

RPP International. (2001). Challenge and opportunity: The impact of charter schools on school districts. Washington, DC: Office of Educational Research and Improvement, U.S. Department of Education.

Sarason, S. (1998). Charter schools: Another flawed educational reform? New York: Teachers College Press.

Solmon, L., Paark, K., \& Garcia, D. (2001). Does charter school attendance improve test scores? The Arizona results. Phoenix, AZ: The Center for Marketbased Education, Goldwater Institute.

SRI International. (1997). Evaluation of charter school effectiveness. Menlo Park, CA: Author. 
SRI International. (2000). Evaluation of the public charter schools program: Year one evaluation report. Washington, DC:

Author.

Teske, P., Schneider, M., Buckley, J., \& Clark, S. (2000). Does charter school competition improve traditional public schools? (Civic Report 10). New York: Center for Civic Education at the Manhattan Institute.

Texas Education Agency. (1999). Texas open-enrollment charter schools: Second-year evaluation 1997-1998. Austin, TX: Author.

Texas Education Agency. (2000). Texas charter schools: Third-year evaluation. Austin, TX: Author.

Vergari, S. (2000). The regulatory styles of statewide charter school authorizers: Arizona, Massachusetts, and Michigan. Educational Administration Quarterly, 36(5), 730-757.

Wells, A. S. (1998). Beyond the rhetoric of charter school reform: A study of 10
California school districts. Los Angeles: UCLA Charter School Study.

WestEd \& University of Southern California. (1998). The findings and implications of increased flexibility and accountability: An evaluation of charter schools in Los Angeles Unified School District. San Francisco: WestEd.

Wohlstetter, P., \& Griffin, N. (1998). Creating and sustaining learning communities: Early lessons from charter schools (Occasional Paper No. OP-03). Philadelphia: Consortium for Policy Research in Education, University of Pennsylvania.

Wohlstetter, P., Wenning, R., \& Briggs, K. L. (1995). Charter schools in the United States: The question of autonomy. Educational Policy, 9(4), 331-358. 